\title{
Laparoscopic Radical Prostatectomy with a Bladder Neck and Urethra Preservation Modified Posterior Approach: Short-term Oncological and Functional Results of the First 108 Patients
}

\author{
Mesane Boynu ve Üretra Koruyucu Modifiyeli Posterior Yaklaşımlı Laparoskopik Radikal \\ Prostatektomi: Illk 108 Hastanın Kısa Dönem Onkolojik ve Fonksiyonel Sonuçları
}

\author{
(D) Şevket Tolga Tombul1', (1) Gökhan Sönmez1', (1) Türev Demirtaş2, (1) Abdullah Demirtaş1 \\ 1 Erciyes University Faculty of Medicine, Department of Urology, Kayseri, Turkiye \\ 2Erciyes University Faculty of Medicine, Department of Medical History and Ethics, Kayseri, Turkiye
}

\section{What's known on the subject? and What does the study add?}

One of the curative treatment options in localized prostate cancer is retropubic radical prostatectomy (RRP). Today, minimally invasive approaches come to the fore in surgical approach. In particular, robotic assisted laparoscopic approach (RLRRP) has found wide use. However, due to the cost burden it brings, it is not accessible to everyone. Laparoscopic radical prostatectomy (LRRP) is therefore still up to date. In this article, the surgical approach that we developed by combining the standart transperitoneal posterior approach technique applied in LRRP with the bladder neck and the urethra preserving technique, which is described in robotic surgery, is presented.

\begin{abstract}
Objective: Short-term oncological and functional results of patients who underwent laparoscopic radical prostatectomy (LRRP) with a bladder neck and urethra preservation modified posterior approach (Demirtaş Erciyes Modification) are presented.

Materials and Methods: The data of 140 patients who were operated between July 2015 and March 2020 for localized prostate cancer were analyzed retrospectively. A total of 32 patients were excluded from evaluation because a history of transurethral prostate resection or bladder neck preservation could not be applied due to the median lobe protruding into the bladder. Preoperative prostate-specific antigen (PSA), prostate biopsies, preoperative erectile function status, operation time, transfusion rate, complications, pathology results of LRRP, postoperative erectile function, and continence status were evaluated.

Results: The mean age of 108 patients was $64 \pm 4.47$ years, with median PSA of $9.65 \mathrm{ng} / \mathrm{mL}$. The mean operation time was $186.96 \pm 54.1$ min, and the median catheter removal time was 10 days. The median hospital stay was 4 days. The median follow-up time was 17.5 months. The prostatectomy pathology of 95\% of patients was at pT2 stage. The complication rate of Clavien 3 and above was 4.6\%. The surgical margin positivity rate was $10.2 \%$. Continence rates were $88 \%$ and $92.6 \%$ at 6 and 12 months, respectively. The rate of erection with spontaneous or oral medications was 43.5\%. Among 58 patients with at least 2 years follow-up, PSA recurrence was detected only in two patients.

Conclusion: Laparoscopic radical prostatectomy with a bladder neck and urethra protective modified posterior approach may be an option in the selected patient group in terms of short-term oncological and functional results.
\end{abstract}

Keywords: Prostate cancer, Laparoscopy, Radical prostatectomy

Öz

Amaç: Mesane boynu ve üretra koruyucu modifiyeli posterior yaklaşımlı (Demirtaş Erciyes Modifikasyonu) laparoskopik radikal prostatektomi uyguladığımız hastaların kısa dönem onkolojik ve fonksiyonel sonuçları sunulmuştur.

Gereç ve Yöntem: Temmuz 2015-Mart 2020 tarihleri arasında lokalize prostat kanseri nedeni ile opere edilen 140 hastanın verileri retrospektif

Correspondence: Abdullah Demirtaș MD, Erciyes University Faculty of Medicine, Department of Urology, Kayseri, Turkiye

Phone: +90 5325094494 E-mail: mesane@gmail.com ORCID-ID: orcid.org/0000-0001-9102-5518

Received: 22.05 .2020

Accepted: 13.07 .2020

Cite this article as: Tombul ŞT, Sönmez G, Demirtaș T, Demirtaş A. Laparoscopic Radical Prostatectomy with a Bladder Neck and Urethra Preservation Modified Posterior Approach: Short-term Oncological and Functional Results of the First 108 Patients. J Urol Surg 2020;7(4):309-315.

๑Copyright 2020 by the Association of Urological Surgery / Journal of Urological Surgery published by Galenos Publishing House. 
olarak incelendi. Otuz iki hastaya transüretral prostat rezeksiyonu öyküsü veya mesaneye indante median lob nedeniyle mesane boynu koruyucu protokol uygulanamadığı için değerlendirme dışı bırakıldı. Preoperatif prostat-spesifik antijen (PSA), prostat biyopsileri patoloji sonuçları, preoperatif ereksiyon durumları, operasyon süresi, transfüzyon miktarı, komplikasyonlar, patolojik sonuçlar, postoperatif ereksiyon ve kontinans durumları değerlendirildi.

Bulgular: Yüz sekiz hastanın ortalama yaşı $64 \pm 4,47$ yıl, median PSA: 9,65 ng/mL'di. Ortalama ameliyat süresi 186,96 $\pm 54,1 \mathrm{dk}$, median 10. gün sonda çekildi. Ortanca yatış günü 4 gündü. Ortanca takip süresi 17,5 aydı. Hastaların \%95'in prostatektomi patolojisi pT2 evresindeydi. Clavien 3 ve üstü komplikasyon oranı \%4,6'ydı. Cerrahi sınır pozitiflik oranı \%10,2'ydi. Kontinans oranları 6 ve 12. ayda sırası ile \%88 ve $\% 92,6$ 'tü. Spontan veya oral medikasyonlar ile ereksiyon sağlanma oranı ise \%43,5'ti. İki yıllık takibi olan 58 hasta içinde sadece iki hastada PSA nüksü tespit dildi.

Sonuç: Mesane boynu ve üretra koruyuculu modifiye posterior yaklaşımlı laparoskopik prostatektomi kısa dönem onkolojik ve fonksiyonel sonuçlar açısından seçilmiş hasta grubunda bir seçenek olabilir.

Anahtar Kelimeler: Prostat kanseri, Laparoskopi, Radikal prostatektomi

\section{Introduction}

Radical prostatectomy is one of the curative treatment options in eligible patients diagnosed with localized prostate cancer (1). With the advancement of technology and surgical experience over time, retropubic radical prostatectomy (RRP) has evolved from an open approach to laparoscopic RRP (LRRP) and ultimately to robot-assisted laparoscopic RRP (RLRRP) $(2,3)$. Complete removal of the tumor, maintenance of continence, and preservation of erectile function in the possible patients are provided at similar rates in all three surgical approaches. Although functional results have been shown to be preserved earlier and to a greater extent in robotic surgery, data show that the same can be observed in the open and laparoscopic approach in the long term. Currently, LRRP and RLRRP are more prominent than RRP in terms of peri- and postoperative results such as length of hospital stay, blood loss, and transfusion rate. Minimally invasive techniques that are advantageous for the patient differ in terms of advantages to the surgeon. Regarding learning time and ergonomics, RLRRP appears to be more surgeon friendly than the other techniques. The most extensively applied RRP technique in the world is robotic surgery. However, compared with LRRP, robotic surgery places an important economic burden on both the patient and the health system. Therefore, for patients and centers that have no access to the robotic system, LRRP remains important as an alternative (4-8).

LRRP was first defined in 1992. Different techniques have been described in the literature with a transperitoneal or retroperitoneal approach from various centers (9-11). Besides oncological results, different modifications have been identified to influence postoperative continence and erection rates. In terms of continence, methods such as bladder neck preservation and membranous urethra preservation have been defined. More effective urethrovesical anastomosis and early continence rates have been demonstrated through these techniques $(12,13)$. Tunc et al. (14) reported early continence after catheter removal with the bladder neck protective method they defined as RLRRP. However, the effectiveness of this technique has not been shown in LRRP. Here, we describe a new laparoscopic approach
(Demirtas Erciyes modification) by combining Montsouris laparoscopic transperitoneal radical prostatectomy with bladder neck and apex preservation described by Tunc et al. (14) for robotic surgery (9). With this modification, the urethral mucosa at the level of the bladder neck and the urethra in the apical region can be fully preserved by laparoscopic dissection.

This study aimed to present the early oncological and functional results of the LRRP series, which we applied with Demirtaş Erciyes modification.

\section{Materials and Methods}

\section{Patient Selection}

The data of 140 patients who underwent LRRP in Erciyes University Department of Urology between July 2015 and March 2020 were analyzed retrospectively. Patients who did not undergo bladder neck and membranous urethra preservation due to previous transurethral prostate resection (TURP) or the median lobe extending into the bladder were excluded. Age, height, weight, preoperative blood count results, PSA value, prostate biopsy pathology results from patient files, risk groups according to European Urology Association (EAU) Prostate Cancer Guidelines and clinical stages, preoperative erectile function determined by short international erectile dysfunction questionnaire (IIEF-5), duration of operation, amount of gas used in the operation, peri- and postoperative transfusion requirement and amount, urethral foley removal times, and periand postoperative complications were determined. PSA levels at postoperative $3^{\text {rd }}, 6^{\text {th }}, 12^{\text {th }}$ and $24^{\text {th }}$ month, postoperative erectile function, and continence status were also recorded $(1,15)$. RRP pathologies and the need for additional postoperative intervention and adjuvant treatment needs were recorded. The developed complications were classified according to the Clavien-Dindo system (16).

\section{Surgical Technique}

RRP was performed with the Montsouris laparoscopic transperitoneal technique via the bladder neck and membranous urethra preservation approach (Demirtaş Erciyes modification). 
All operations were performed by a single surgeon (A. Demirtas) with more than 15 years of experience in genitourinary laparoscopy. The steps in this technique are as follows:

1. The patient was positioned in dorsal lithotomy with the lower extremity flexion abduction. A Veress needle punctured through abdominal wall layers under the umbilicus. Pneumoperitoneum was provided with $14 \mathrm{~atm}$. Skin layers were incised at that point, and a $10 \mathrm{~mm}$ camera trocar was placed under the umbilicus. The abdominal cavity was inspected for possible injury by using a $10 \mathrm{~mm} 30{ }^{\circ} \mathrm{C}$ laparoscope. Subsequently, two right and two left working trocars were placed. A $5 \mathrm{~mm}$ trocar was used in the left iliac region. The others were $10 \mathrm{~mm}$. Subsequently, the pressure was dropped to $12 \mathrm{~atm}$.

2. The posterior peritoneum at the Douglas pouch was incised at the level of the vas deferens. Bilateral vas deferens and seminal vesicles were completely released. The seminal vesicle arteries were cut with the help of bipolar cautery. Bilateral vas deferenses were separated from the proximal ends with polymer ligation clips. The posterior aspect of the denonvillier fascia was opened, and the posterior aspect of the prostate was dissected over the pre-rectal fatty tissue toward the apex.

3. Subsequently, the bladder was inflated with $100 \mathrm{~mL}$ of $0.09 \%$ saline, and the anterior wall of the peritoneum was opened through the umbilical ligament. A cavity was created in the retroperitoneal area until reaching the pelvic floor. The bilateral endopelvic fascia was opened, and apical dissection was performed. Muscle fibers from the external sphincter were dissected. Puboprostatic ligaments were cut. The dorsal vein complex was ligated with a $2.0 \mathrm{~V}$ Lock $^{\circledR}$ (Medtronic, MN, USA) barbed suture and cut with an ultrasonic dissector. Subsequently, apical dissection was completed. Membranous urethra was exposed, and the posterior aspect of the urethra was released. A dissection was made between the apex and the urethra.

4. With the traction of a foley catheter, the junction between the prostate and bladder was defined. Detrusor fibers were cut with an ultrasonic dissector from the bladder neck. The urethra was completely poured at the level of the bladder neck. The urethra was cut with scissors. The balloon of the foley catheter was deflated, and the foley was pulled back to the prostate base. The prostate was raised by pulling up the catheter tip with a dissector. Posteriorly, the prostate was separated from the bladder, and the space between the prostate and rectum was observed. Both seminal vesicles and vas deferens were delivered. In patients suitable for bilateral or unilateral nerve sparing, the neurovascular bundle was separated from the prostate toward the pelvic floor by sharp dissections without using energy. At this level, the prostatic vessels were cut with polymer ligation clips. When the apical region was reached, the urethra was cut from the apex level. Posterior parts of the apex were dissected. The specimen was placed into the specimen bag. Bleeding was controlled by bipolar cauterization. Bilateral pelvic lymph node dissection was performed in patients who needed lymph node dissection according to EAU risk classification and Briganti nomogram before urethrovesical anastomosis $(1,17)$. Urethrovesical anastomosis was started in the direction of 3 o'clock, and continuous suturing was completed with a single suture with 3.0 Stratafix ${ }^{\circledR}$ with a $27 \mathrm{~mm}$ stitching (Ethicon, USA) in counterclockwise direction. After anastomosis, the bladder was inflated with $150 \mathrm{~mL}$ of $0.9 \%$ saline solution, and leakage control of anastomosis was achieved. A drain tube was placed on the surgical area through the trocar line on the lower right quadrant. The trocar line below the umbilicus was enlarged, and the specimen was removed. At the end of the operation, if bleeding was detected from the trocar lines, the trocar line was sutured with the help of a laparoscope; when it could not be done, $16 \mathrm{Fr}$ foley was placed on the trocar line, and the balloon was inflated with $20 \mathrm{~mL}$ and foley traction was performed. In the absence of bleeding on the $2^{\text {nd }}$ or $3^{\text {rd }}$ day during postoperative follow-up, the foley catheter in the trocar line was removed. Otherwise, all trocar lines were closed subcutaneously. If there was no leakage from the anastomosis line in cystography on the $10^{\text {th }}$ postoperative day, urethral foley catheter and drain tube were removed.

\section{Statistical Analysis}

Data were analyzed using Statistical Package for Social Sciences (SPSS) version 22.0 (IBM Corp. Released 2013. IBM SPSS Statistics for Windows, Version 22.0. Armonk, NY: IBM Corp.). Distribution patterns of data were determined by the Shapiro-Wilk test and histogram plots. Continuous variables with normal distribution were expressed as mean \pm standard deviation, and the variables without normal distribution were expressed as median (minmax). Categorical variables were expressed as percentages (\%).

\section{Ethic Approval}

The study was approved by Erciyes University Clinical Research Ethics Committee (approval number: 2020/274).

\section{Results}

\section{Surgical and Oncological Results}

Of the 140 patients whose data were evaluated, 32 patients who did not undergo bladder neck and membranous urethra preservation due to huge median $(n=20)$ lobe or previous TUR-P $(n=12)$ were excluded from the study. The mean age of 108 patients included in the study was $64 \pm 4.47$ years, and the median PSA value was $9.65 \mathrm{ng} / \mathrm{mL}$ (6.70-14.0). About 52\% of the patients had abnormality (hardness and/or nodule) in digital rectal examination. The median follow-up time was 17.5 months 
(6-26). All patients were diagnosed with transrectal ultrasoundguided prostate needle biopsy (TRNB). Tumor grade in 79.6\% of preoperative TRNB histopathology consisted of groups 1 and 2 according to the International Society of Urological Pathology (ISUP) classification. Preoperative, intraoperative, and postoperative characteristics are presented in Tables 1 and 2. There was no conversion to open surgery. On the basis of radical prostatectomy pathologies, there was an upgrade of ISUP groups in 34 patients (31.5\%). Positive surgical margin was present in 8 patients (7.4\%), extracapsular extension was noted in 7 patients $(6.4 \%)$, and both positive surgical margin and extension beyond the capsule were observed in 3 patients (2.7\%). Surgical margin positivity on the bladder neck was present only in $2(1.85 \%)$ patients. Positive surgical margin rates for pT2 and pT3 stages were $6.31 \%(n=6)$ and $38.5 \%(n=5)$, respectively. Pelvic lymph node dissection was conducted in 23 patients. Lymph node metastasis was detected only in one of them (4.3\%). When the PSA values of 58 patients with a followup period of at least 2 years were examined, PSA recurrence was detected in 2 patients. These patients were in the pT3b stage, so salvage radiotherapy and hormonotherapy were applied to them. Six patients in the same group were at pT3a and pT3b stages. Four of them preferred adjuvant radiotherapy, and the remaining two preferred follow-up; they had no PSA recurrence.

\section{Complications}

For intraoperative complications, 3 patients (2.8\%) had bleeding at the trocar line, 1 patient (0.9\%) had perforation in the bladder dome, 1 patient (0.9\%) had an opening in the rectum serosa, and 2 patients (1.9\%) had rectum perforation. Bladder perforation and rectum serosal injury were noticed intraoperatively and repaired in the same session. Rectal perforation occurred in 2 patients $(1.9 \%)$. One of the rectum perforations was detected and repaired during laparoscopy. However, due to the development of a rectovesical fistula after catheter removal, abdominal exploration was performed, and a colostomy was opened. During follow-up, the recto-vesical fistula was repaired colonoscopically and his colostomy was closed. The other rectum perforation was diagnosed with acute abdomen on the $5^{\text {th }}$ postoperative day. Urgent abdominal exploration was performed, and colostomy was conducted. However, the patient died due to sepsis during follow-up. In the postoperative period, paralytic ileus in 8 patients (7.4\%) who recovered with conservative management, urinary tract infection in 6 patients $(5.6 \%)$ who were given antibiotic therapy, ureter ligation in 1 patient $(0.9 \%)$, and prolonged drainage in 5 patients $(4.6 \%)$ were detected. Ureter ligation was diagnosed with flank pain and hydronephrosis. Percutaneous nephrostomy was placed on the ligated side. Open ureteroneocystostomy was performed in the 2 months after LRRP. Intraoperative or postoperative erythrocyte transfusion was performed in 14 patients (12.9\%). Erythrocyte transfusion of 2 units and above was performed in 6 patients (5.6\%). In 5 patients (4.6\%), bladder neck stricture was developed at 6 months after surgery. These patients underwent endoscopic bladder neck resection. Two of these patients had adjuvant radiotherapy. One patient came with hematuria during the first-year follow-up. As a result of cystoscopy and transurethral resection, a muscle-invasive bladder tumor was detected. The patient underwent radical cystectomy and urinary diversion. When the developed complication was classified according to the Clavien-Dindo classification, grade 1, 2, 3b, and 4 complication rates were $13.9 \%(n=15), 13.9 \%(n=15), 3.7 \%$ $(n=4)$, and $0.9 \%(n=1)$, respectively.

\section{Continence and Potency}

Two patients (1.85\%) had total incontinence; six patients (5.55\%) had incontinence, which would require the use of two or more pads a day after the operation. The remaining patients had complete continence or stress incontinence requiring one safety pad usage per day. The percentages of patients who were continent or used one safety pad per day at the $3^{\text {rd }}, 6^{\text {th }}$, and $12^{\text {th }}$

Table 1. Preoperative and peroperative characteristic of patients

\begin{tabular}{|c|c|}
\hline & $N=108$ \\
\hline Age (years) & $64 \pm 4,47$ \\
\hline Preoperative PSA (ng/mL) & $9.65(6.70-14)$ \\
\hline Abnormal DRE n (\%) & $57(\% 52.8)$ \\
\hline \multicolumn{2}{|l|}{ TRUS- ISUP n (\%) } \\
\hline 1 & $65(60.2 \%)$ \\
\hline 2 & $21(19.4 \%)$ \\
\hline 3 & $9(8.3 \%)$ \\
\hline 4 & $10(9.3 \%)$ \\
\hline 5 & $3(2.8 \%)$ \\
\hline \multicolumn{2}{|l|}{ EAU prostate cancer risk group } \\
\hline Low & $44(40.7 \%)$ \\
\hline Intermediate & $41(38 \%)$ \\
\hline High & $23(21.3 \%)$ \\
\hline IIEF score & $14(8-18)$ \\
\hline Operation time (min) & $186.96 \pm 54.1$ \\
\hline Nerve Sparing & $85(78.7 \%)$ \\
\hline Unilateral & $36(33.3 \%)$ \\
\hline Bilateral & $49(45.4 \%)$ \\
\hline Non-nerve sparing & $23(21.3 \%)$ \\
\hline Pelvic lymph node dissection & $23(21.3 \%)$ \\
\hline Catheter removal time (min-max) & $10(10-20)$ \\
\hline Hospital stay & $4(3-6.75)$ \\
\hline
\end{tabular}


Table 2. Oncologic and functional outcomes of patients

\begin{tabular}{|l|l|}
\hline \multicolumn{2}{|l|}{ N (\%) } \\
\hline 1 & $48(44.4 \%)$ \\
\hline 2 & $28(25.9 \%)$ \\
\hline 3 & $12(11.1 \%)$ \\
\hline 4 & $15(13.9 \%)$ \\
\hline 5 & $2(4.6 \%)$ \\
\hline ISUP upgrade after RRP $\mathrm{n}(\%)$ & $34(31.5 \%)$ \\
\hline T stage & $8(7.4 \%)$ \\
\hline T2a & $19(17.6 \%)$ \\
\hline T2b & $68(63 \%)$ \\
\hline T2c & $9(8.3 \%)$ \\
\hline T3a & $4(3.7 \%)$ \\
\hline T3b & $11(10.2 \%)$ \\
\hline Positive surgical margin $\mathrm{n}(\%)$ & $10(9.3 \%)$ \\
\hline Extracapsular extension $\mathrm{n}(\%)$ & $100(92.6)$ \\
\hline Continence rate at the $1^{\text {st }}$ year & $48(56.5 \%)$ \\
\hline Erectile dysfunction rate & $17.5(6-26)$ \\
\hline Median Follow-up (25 $\left.{ }^{\text {th }}-75^{\text {th }}\right)$ in months & \\
\hline $\begin{array}{l}\text { ISUP: International Society of Urological Pathology, RRP: } \\
\text { prostatectomy }\end{array}$ & \\
\hline
\end{tabular}

months were $73.2 \%, 88 \%$, and $92.6 \%$, respectively.

Neurovascular bundle preservation was performed in 85 patients. Erection was achieved spontaneously in 3 patients (3.5\%), with tadalafil in 6 patients $(7 \%)$, and with intracavernous agent (papaverine or alprostadil) in 28 patients (32.9\%). In 16 patients $(18.8 \%)$ who received intracavernous injection, erection could not be achieved. A total of 32 patients (37.8\%) did not accept the suggested treatments. Meanwhile, erectile dysfunction persisted in 48 postoperative patients (56.5\%), and spontaneous erection or erection with medication was achieved in 37 patients $(43.5 \%)$.

\section{Discussion}

Radical prostatectomy is a complex surgical procedure applied in localized prostate cancer. The development that started with open retropubic prostatectomy has evolved into LRRP and then to RLRRP. In this process, many different techniques have been defined in the literature. As the surgical experience increased, the targets were kept high in functional and oncological results, and successes at varying rates were reported. Current data revealed similar success rates in all three approaches in terms of oncological results, but different views were expressed in terms of continence and erection preservation rates. With the emergence of minimally invasive surgical techniques, short hospitalization times, minimal bleeding, and low transfusion rates have emerged. Although robotic surgery appears to be one step ahead in this sense, it is ahead in terms of cost compared with the open and laparoscopic approach. However, robotic surgery causes high costs both to patients and hospitals. Therefore, robotic RRP is not always an easily accessible method, and laparoscopic RRP appears as a minimally invasive treatment option (1,3,5-7). In addition to the previously described surgical techniques in the laparoscopic approach, different techniques have been defined to provide better continence and potency rates. In recent years, some of the surgical modifications defined for RLRRP have been applied in LRRP. This paper presents the results of our series with 108 patients who were subjected to a modified technique (Erciyes modification) by combining the bladder neck and membranous urethra preservation described by Tunc et al. (14) for RLRRP and the transperitoneal Montsouris technique (9).

The following perioperative data were obtained: operation time, transfusion rate, catheter time, hospitalization day, and general complication rates of $186.96 \pm 54.0 \mathrm{~min}, 12.9 \%, 10$ days, 4 (3$6.75)$ days, and $32.4 \%$, respectively. In a review comparing the open RRP, LRRP, and RLRRP series, De Carlo et al. (6) reported the following for LRRP: operation time, transfusion rate, catheter time, hospitalization day, and general complication rates of $236.54 \mathrm{~min}, 6.3 \%, 10.32$ days, 9.02 days, and $13.42 \%$, respectively. In a similar review, Tooher et al. (18) reported these rates as $239 \mathrm{~min}, 17 \%, 3 \%, 8.4$ days, 5.8 days, and $11 \%$. Operation time, catheter duration, and hospital stay in this cohort were consistent with the literature. However, transfusion and general complication rates were higher in our series than in the literature. When we examined our data, we found that this rate $(18.5 \%)$ was more pronounced, especially in the first 54 patients. In the last 54 patients, this rate (7.4\%) had decreased significantly. Therefore, the difference from the literature may be attributed to the "learning curve." When we examined the complication distribution, the Clavien-Dindograde I and II ratio was $27.8 \%$, whereas grade III and IV complications requiring additional intervention were only $4.6 \%$.

When oncological results were reviewed, the results indicated that $88 \%$ of the patients were in $\mathrm{pT} 2,8.3 \%$ were in $\mathrm{pT} 3 \mathrm{a}$, and $3.7 \%$ were in $\mathrm{pT} 3 \mathrm{~b}$ stage after RRP. Surgical margin positivity was $10.2 \%$. The surgical margin positivity for pT2 and pT3 was $6.31 \%$ and $38.5 \%$, respectively. Downgrading of the ISUP group was observed in $31.5 \%$ of patients according to biopsy pathologies. Given that the follow-up period was short, oncological data such as 5-year disease-free survival and biochemical recurrence rates could not be provided. However, on the basis of the data of patients who were followed up for at least 2 years, only two patients exhibited PSA recurrence. Salvage radiotherapy and hormonal therapy were given to these two patients. In the meta-analysis of De Carlo et al. (6), they reported general 
surgical margin positivity and surgical margin positivity for pT2 and pT3 as $22.04 \%, 17.44 \%$, and $49.61 \%$, respectively; Tooher et al. (18) reported these rates as $23 \%, 10 \%$, and $40 \%$, respectively. Compared with the literature data, our short-term oncological results appeared to be promising. However, we should not ignore that the majority of our patients constituted a low- and intermediate-risk prostate cancer group.

Only $8(7.4 \%)$ of our patients had total incontinence or needed to use two or more pads per day at the end of one year. The $3^{\text {rd }}$ and $12^{\text {th }}$ month continence rates were $73.2 \%$ and $92.6 \%$, respectively. Tunc et al. (14), who defined bladder neck preservation for RLRRP, reported a 100\% continence rate as soon as the catheter was withdrawn in their series. In metaanalyses containing LRRP, continence rates between $70 \%$ and $80 \%$ after 1 year were reported $(6,12,18)$. Our continence rate was better than that of laparoscopic RRP but relatively poor in the early period compared with robotic surgery at which the original bladder neck preservation technique was described. However, after 1 year, we reached the results of continence close to robotic surgery. We believe that this difference between the early continence rates was due to the technological advantage in image magnification in robotic surgery. In terms of erection function, 85 patients were suitable for the nerve sparing option. Erection was achieved in $3(3.5 \%)$ of them spontaneously, in 6 (7\%) of them with phosphodiesterase-5 inhibitors, and in 28 $(32.9 \%)$ of patients with intracavernous agents. Erection was never achieved in 56.5\% of the patients. However, 32 patients $(37.8 \%)$ in this group did not accept the additional treatment suggestion. In the literature, potency rates are between 35\% and $41 \%$ in laparoscopy series $(5,6,18)$. Our erectile function preservation rate (spontaneous erection or erection with medication) seems low despite nerve sparing. Two important factors may be attributed to this result. First, the preoperative erectile function median IEEF score was 14 in our cohort, indicating that our group of patients already had erection dysfunction. Second, the neurovascular bundle dissection experience should be improved.

Our laparoscopic RRP technique has a relatively good erectile function preservation rate and near-perfect oncological and continence results. However, the presented article has some shortcomings. First, this study contained only one arm and no comparison group. Second, it involved a relatively low number of patients. Given the lack of long-term results, oncological data such as cancer-specific survival and progression-free survival have not been provided. Another point that can be criticized is that most of the patients in our cohort had a diagnosis of low- or intermediate-risk prostate cancer. Finally, the technique we tried to define is unsuitable for every patient candidate for
LRRP. It is not applicable to patients with prominent median lobe or history of TURP.

\section{Conclusion}

Transperitoneal LRRP with bladder neck and urethra preservation LRRP with the posterior approach (Demirtas Erciyes modification) yields adequate oncological and functional results in the selected patient group. However, comparative studies with long-term follow-up are needed for definitive judgment.

\section{Ethics}

Ethics Committee Approval: The study was approved by Erciyes University Clinical Research Ethics Committee (approval number: 2020/274).

Informed Consent: Retrospective study.

Peer-review: Externally and internally peer-reviewed.

\section{Authorship Contributions}

Surgical and Medical Practices: A.D., Concept: Ş.T.T., A.D., Design: S..T.T., A.D., Data Collection or Processing: S.T.T., G.S., T.D., Analysis or Interpretation: S..T.T., G.S., T.D., A.D., Literature Search: Ş.T.T., Writing: S.T.T., A.D.

Conflict of Interest: No conflict of interest was declared by the authors.

Financial Disclosure: The authors declared that this study received no financial support.

\section{References}

1. Mottet $N$, Bellmunt J, Bolla $M$, Briers $E$, Cumberbatch $M G$, De Santis $M$, Fossati N, Gross T, Henry AM, Joniau S, Lam TB, Mason MD, Matveev VB, Moldovan PC, vanden Bergh RCN, Van den Broeck T, van der Poel HG, van der Kwast TH, Rouvière 0 , Schoots IG, Wiegel T, Cornford P. EAU-ESTROSIOG Guidelines on Prostate Cancer. Part 1: Screening, Diagnosis, and Local Treatment with Curative Intent. Eur Urol 2017;71:618-629.

2. Eggleston JC, Walsh PC. Radical prostatectomy with preservation of sexualfunction: pathological findings in the first 100 cases. J Urol 1985;134:1146-1148.

3. Montorsi F, Wilson TG, Rosen RC, Ahlering TE, Artibani W, Carroll PR, Costello A Eastham JA, Ficarra V, Guazzoni G, Menon M, Novara G, Patel VR, Stolzenburg JU, Van der Poel H, Van Poppel H, Mottrie A, Pasadena Consensus Panel. Bestpractices in robot-assisted radical prostatectomy: recommendations of the Pasadena Consensus Panel. Eur Urol 2012;62:368-381.

4. Basiri A, de la Rosette JJ, Tabatabaei S, Woo HH, Laguna MP, Shemshaki H. Comparison of retropubic, laparoscopic and robotic radical prostatectomy: who is the winner? World J Urol 2018;36:609-621.

5. Caillet K, Lipsker A, Alezra E, De Sousa P, Pignot G. [Surgical approach andsexual outcomes after radical prostatectomy]. Prog Urol 2017;27:283296.

6. De Carlo F, Celestino F, Verri C, Masedu F, Liberati E, Di Stasi SM. Retropubic laparoscopic, and robot-assisted radical prostatectomy: surgical, oncological, and functional outcomes: a systematic review. Urol Int 2014;93:373-383. 
7. Tandogdu Z, Vale L, Fraser C, Ramsay C. A Systematic Review of Economic Evaluations of the Use of Robotic Assisted Laparoscopy in Surgery Compared with Open or Laparoscopic Surgery. Appl Health Econ Health Policy 2015;13:457-467.

8. Schuessler WW, Schulam PG, Clayman RV, Kavoussi LR. Laparoscopic radicalprostatectomy: initial short-term experience. Urology 1997;50:854857.

9. Guillonneau B, Cathelineau X, Barret E, Rozet $F$, Vallancien G. Laparoscopicradical prostatectomy: technical and early oncological assessment of 40 operations. Eur Urol 1999;36:14-20.

10. Rassweiler J, Sentker L, Seemann O, Hatzinger M, Stock C, Frede T. Heilbronn laparoscopic radical prostatectomy. Technique and results after 100 cases. Eur Urol 2001;40:54-64.

11. Cathelineau $X$, Sanchez-Salas R, Barret E, Rozet F, Galiano M, Benoist N, Stakhovsky 0, Vallancien G. Radical prostatectomy: evolution of surgical technique from the laparoscopic point of view. Int Braz J Urol 2010;36:129139; discussion 140.

12. Nyarangi-Dix JN, Radtke JP, Hadaschik B, Pahernik S, Hohenfellner M. Impact of complete bladder neck preservation on urinary continence, quality of life and surgical margins after radical prostatectomy: a randomized, controlled, single blind trial. J Urol 2013;189:891-898.
13. Salazar A, Regis L, Planas J, Celma A, Díaz F, Gallardo I, Trilla E, Morote J. Early continence after radical prostatectomy: A systematic review. Actas Urol Esp 2019;43:526-535.

14. Tunc L, Gumustas H, Akin Y, Atkin S, Peker T, Erdem O, Bozkirli I. A novel surgical technique for preserving the bladder neck during robot-assisted laparoscopic radical prostatectomy: preliminary results. J Endourol 2015;29:186-191.

15. Turunç $T$, Deveci $S, G u ̈ v e l ~ S$, Peşkircioğlu L. The assessment of Turkish Validation with 5 Question Version of International Index of Erectile Function (IIEF-5) Turk J Urol 2007;33:45-49.

16. Dindo D, Demartines N, Clavien PA. Classification of surgical complications: anew proposal with evaluation in a cohort of 6336 patients and results of a survey. Ann Surg 2004;240:205-213.

17. Briganti $A$, Larcher $A$, Abdollah F, Capitanio U, Gallina A, Suardi N, Bianchi $M$, Sun $M$, Freschi M, Salonia A, Karakiewicz PI, Rigatti $P$, Montorsi $F$. Updated nomogram predicting lymph node invasion in patients with prostate cancer undergoing extended pelvic lymph node dissection: the essential importance of percentage of positive cores. Eur Urol 2012;61:480487.

18. Tooher R, Swindle P, Woo H, Miller J, Maddern G. Laparoscopic radical prostatectomy for localized prostate cancer: a systematic review of comparative studies. J Urol 2006;175:2011-2017. 